\title{
CYTOMEGALOVIRUS IN COLORECTAL CANCER AND IDIOPATHIC ULCERATIVE COLITIS
}

\begin{abstract}
SUMMARY
Cytomegalovirus (CMV) is a genus in the family Herpesviridae that has been associated with gastrointestinal syndromes. In this work we looked for a possible association of CMV infection with colorectal cancer and ulcerative colitis (UC). Blood and enteric tissue samples of 14 patients with colorectal cancer and of 21 with UC were subjected to a nested-PCR that amplifies part of the gB gene of CMV and also to immunohistochemistry using a specific monoclonal antibody to IE 76kDa protein of CMV. CMV was detected by nested-PCR in the blood and/or the enteric tissue of nine (64.3\%) colorectal cancer and $16(76.2 \%)$ ulcerative colitis patients. In the immunohistochemistry it was observed that $12(12 / 21,57.1 \%)$ positive enteric tissue samples of patients with UC and none from patients with colorectal cancer (0/14) were positive to CMV. The positivity of CMV infections in the UC patient group $(12 / 21,57.1 \%)$ showed by both techniques, was significantly higher $(p=0.015)$ than that observed for colorectal cancer patients $(2 / 14,14.3 \%)$. These results suggest an association of ulcerative colitis with CMV infection of the enteric tissue.
\end{abstract}

KEYWORDS: Cytomegalovirus; Colorectal cancer; Ulcerative colitis; Polymerase chain reaction; Immunohistochemistry.

\section{INTRODUCTION}

Cytomegalovirus (CMV) is a genus in the $\beta$ Herpesvirinae subfamily of the Herpesviridae. CMV is a common causative of gastrointestinal tract diseases in immunodeficient patients, leading to a high morbidity and mortality ${ }^{10}$. CMV disease can occur in all locations of the gastrointestinal tract, from mouth to rectum and, usually, produces ulcers in the mucosa, commonly followed by bleeding. CMV has been reported in the tissues of colorectal cancer, glioma malignant and neoplasm of prostate $^{8}$. Besides, CMV genome and proteins have been detected in cells of solid neoplasms and not at the normal adjacent tissues ${ }^{3,8}$. However, the relation of CMV infection with colorectal cancer is still unclear and divergent. CMV infection has also been described as a causative of idiopathic ulcerative colitis, a chronic illness of inflammatory nature and unknown etiology9. Although there have been a gradual increasing number of case reports of CMV infection complicating ulcerative colitis, there are few reports on its prevalence ${ }^{19,21}$.

In the present study we examined blood and enteric tissue samples of colorectal cancer and ulcerative colitis patients for the presence of CMV DNA and proteins by PCR and immunohistochemistry tests, respectively.

\section{MATERIAL AND METHODS}

Fourteen individuals with colorectal cancer and 21 individuals with ulcerative colitis followed, from March 2002 to May 2004, in the Division of Gastroenterology of the General Hospital of the School of Medicine of the University of São Paulo in Ribeirão Preto City (GHSMUSPRP), Brazil, participated of this study. Seven of the ulcerative colitis participants were receiving immune suppressor drugs (azathioprine in four patients, and/or parenteral steroid in five) for at least three months before the sample collection and were considered as immune suppressed. Whole blood samples were collected by venipuncture using EDTA as anticoagulant and enteric tissue samples were obtained by biopsy during endoscopic examination or surgery. These samples were tested for the presence of CMV genome by nestedPCR or antigens by immunohistochemistry. This research project was approved by the Ethic Board of the GHSMUSPRP (Process 3285/2002).

DNA purification: For separation of peripheral blood leukocytes (PBL), $5 \mathrm{~mL}$ of EDTA-treated whole blood samples were processed immediately after collection. Briefly, $1 \mathrm{~mL}$ of $1 \%$ dextran was added to each blood sample and the mixture was incubated at $37^{\circ} \mathrm{C}$ for $30 \mathrm{~min}$. Ten $\mathrm{mL}$ of PBS were added to the supernatant fluids and centrifuged at $300 \mathrm{~g}$ for seven min. The PBL pellets were washed in $10 \mathrm{~mL}$ of PBS, centrifuged and resuspended in $200 \mu \mathrm{L}$ of PBS. The DNA was extracted using the QIAamp DNA Blood Kit (Qiagen, Germany), according to the manufacturer recommendations. The enteric tissue samples were prepared for DNA extraction by crushing the tissue in $200 \mu \mathrm{L}$ of PBS. For DNA extraction these samples were processed by phenol/chloroform method ${ }^{16}$. Each DNA extract was resuspended in

Research supported by CNPq and Fapesp

(1) Virology Research Center, School of Medicine, University of São Paulo in Ribeirão Preto City, SP, Brazil.

(2) Department of Internal Medicine, School of Medicine, University of São Paulo in Ribeirão Preto City, SP, Brazil.

(3) Department of Pathology, School of Medicine, University of São Paulo in Ribeirão Preto City, SP, Brazil.

Correspondence to: Luiz Tadeu Moraes Figueiredo, Virology Research Center, School of Medicine of Ribeirão Preto, University of São Paulo, Av. Bandeirantes 3900, 14049-900 Ribeirão Preto, São Paulo, Brazil. Phone: +55.16.3602-4508, Fax: +55.16.3602-3376. E-mail: vivibiologia@yahoo.com.br. 
$200 \mu \mathrm{L}$ of DNAse/RNAse free water, quantified by spectrophotometry using the Genequant equipment (Amershan, USA), and stored at $-70^{\circ} \mathrm{C}$ until use.

Nested-PCR: The nested-PCR was carried out as described by AQUINO et al., 2001 ${ }^{1}$. The reaction mixture of the PCR contained, in a total volume of $50 \mu \mathrm{L}, 75 \mathrm{mM}$ of Tris- $\mathrm{HCl}$ (pH 9), $2 \mathrm{mM}$ of $\mathrm{MgCl}_{2}$, $50 \mathrm{mM}$ of $\mathrm{KCl}, 20 \mathrm{mM}$ of $\left(\mathrm{NH}_{4}\right) 2 \mathrm{SO}_{4}, 50 \mu \mathrm{M}$ of each one of the deoxynucleoside triphosphates, $0.3 \mu \mathrm{M}$ of primers gB1 and gB2 (shown in Table 1) and $1 \mu \mathrm{g}$ of DNA obtained from PBLs and enteric tissue. The reaction mixture was first incubated at $94{ }^{\circ} \mathrm{C}$ for three min, the temperature was reduced to $80{ }^{\circ} \mathrm{C}$, and $1 \mathrm{U}$ of Taq DNA polymerase was added. The PCR mixture was subjected to 15 cycles of $60 \mathrm{sec}$ at $94{ }^{\circ} \mathrm{C}, 120 \mathrm{sec}$ at $65^{\circ} \mathrm{C}$, and $120 \mathrm{sec}$ at $72^{\circ} \mathrm{C}$, and to 30 cycles at $94^{\circ} \mathrm{C}$ for $60 \mathrm{sec}, 55^{\circ} \mathrm{C}$ for $90 \mathrm{sec}, 72{ }^{\circ} \mathrm{C}$ for $120 \mathrm{sec}$, and finally, to three min at $72{ }^{\circ} \mathrm{C}$. Two $\mu \mathrm{L}$ of this reaction were used in a nested-PCR containing the same components mentioned above, except for the internal primers gBN1 and gBN2 (Table 1). The reaction mixture was first incubated at $94{ }^{\circ} \mathrm{C}$ for three min, the temperature was reduced to $80^{\circ} \mathrm{C}$, and $1 \mathrm{U}$ of Taq DNA polymerase was added. The PCR mixture was subjected to 30 cycles of $60 \mathrm{sec}$ at $94{ }^{\circ} \mathrm{C}, 60 \mathrm{sec}$ at $55^{\circ} \mathrm{C}, 60 \mathrm{sec}$ at $72{ }^{\circ} \mathrm{C}$, and finally to three min at $72{ }^{\circ} \mathrm{C}^{4}$. Negative samples were subjected to a PCR for $\beta$-globin gene amplification, as a control for false negative results, confirming the integrity of DNA extracts and of the reaction mixture, as well as checking the efficacy of the PCR thermal cycles? PCR and nested-PCR products were subjected to electrophoresis in a $2 \%$ agarose gel and the amplicon bands were visualized by UV after ethidium bromide staining.

Table 1

Primers used in the PCR and in the nested-PCR for CMV and in the PCR for $\beta$-globin gene

\begin{tabular}{ll}
\hline Primer & Nucleotide sequence \\
\hline gB1 & 5' GAAACGCGCGGCAATCGG 3' \\
gB2 & 5' TGGAACTGGAACGTTTGGC 3' \\
gBN1 & 5' GCGCCGTTGATCCACACACC 3' \\
gBN2 & 5' TACGCCCAGCTGCAGTTCAC 3' \\
RS42 & 5' GCTCACTCAGTGTGGCAAAG 3' \\
KM29 & 5' GGTTTGGCCAATCTACTCCCAGG 3' \\
\hline
\end{tabular}

Immunohistochemistry: All tissue samples have been routinely fixed in $4 \%$ neutral formalin and embedded in paraffin. Briefly, 4- $\mu \mathrm{m}-$ thick sections were cut from paraffin blocks containing representative samples. Paraffin sections were de-waxed in xylene, rehydrated through a series of graded alcohols, placed in $10 \mathrm{mM}$ citrate buffer and submitted to heat retrieval using a vapor lock for $45 \mathrm{~min}$. After heating, the slides were allowed to cool to room temperature and briefly washed with PBS. Endogenous peroxidase activity was blocked with 3\% hydrogen peroxide for five min. Normal serum (Novocastra Universal Quick Kit, UK) was used for $10 \mathrm{~min}$ in order to block nonspecific immunoassaying. Immunohistochemical staining was performed using a streptavidin-biotin peroxidase system (Novocastra Universal Quick Kit, UK). The primary antibody NCL-CMV-IE/EA that recognizes IE $76 \mathrm{kDa}$ protein of CMV (1:100, clone DDG9 and CCH2, Novocastra, $\mathrm{UK}$ ) was incubated for one $\mathrm{h}$ at room temperature. Following washes in PBS, biotinylated universal secondary antibody (Novocastra
Universal Quick Kit, UK) was applied for 10 min. The sections were incubated with the streptavidin-biotin complex reagent (Novocastra Universal Quick Kit, UK) for five min and developed with 3.3diaminobenzidine tetrahydrochloride (Liquid DAB Substrate Kit, Novocastra, UK) for five min. Finally, the slides were counterstained with hematoxylin of Mayer and mounted with Permount (Fisher Scientific, USA). Cells with nucleus or edge with brown staining were considered positive for CMV. The analysis looking for presence of CMV antigen was only qualitative.

Statistical analysis: The Fisher's exact test, which is especially suited for small sets of data, was used with $p$ values equal or under 0.05 to determine the strength of association between the investigated parameters. Calculations were performed by Instat software (Graph Pad, USA).

\section{RESULTS}

CMV was detected by nested-PCR in the blood and/or the enteric tissue of nine $(64.3 \%)$ colorectal cancer and $16(76.2 \%)$ ulcerative colitis patients. Differences on prevalence of CMV in blood and/or tissues of the colorectal cancer and ulcerative colitis participants were not significant, as shown in Table 2 .

Table 2

Positivity for CMV in blood leukocytes and enteric tissues of the two groups of patients

\begin{tabular}{lccc}
\hline Samples & $\begin{array}{c}\text { Colorectal } \\
\text { cancer }\end{array}$ & $\begin{array}{c}\text { Ulcerative } \\
\text { colitis }\end{array}$ & $p$ value \\
\hline Blood & $64.3 \%(9 / 14)$ & $66.7 \%(14 / 21)$ & 1.00 \\
Enteric tissue & $14.3 \%(2 / 14)$ & $57.1 \%(12 / 21)$ & $\mathbf{0 . 0 1 5 6}$ \\
Blood/tissue & $64.3 \%(9 / 14)$ & $76.2 \%(16 / 21)$ & 0.4736 \\
\hline
\end{tabular}

CMV was detected in nine (64.3\%) blood samples and two (14.3\%) enteric tissue samples of patients having colorectal cancer. In the participants with ulcerative colitis, CMV was detected in the blood samples of 14 cases $(66.7 \%)$ and in tissue samples of 11 cases $(52.4 \%)$ as shown in Figure 1. Therefore, a higher frequency of CMV was observed in the blood samples than in the enteric tissue samples by both techniques and for both studied groups (23/35 or $65.7 \%$ and $14 /$ 35 or $40 \%$, respectively) $(p=0.054)$.

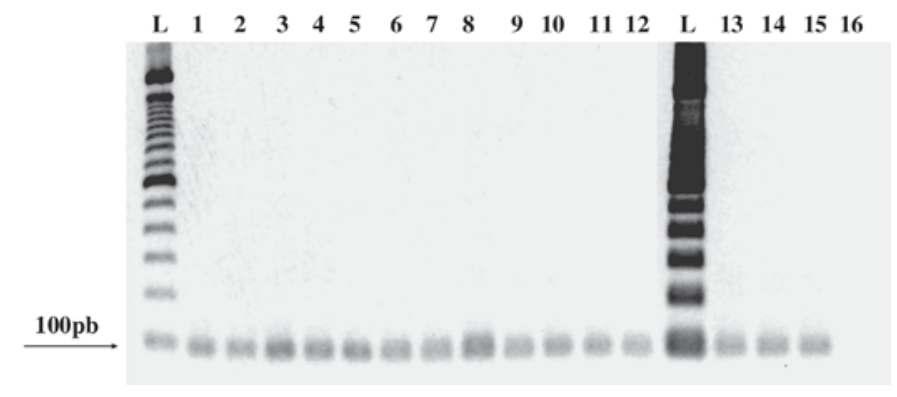

Fig. 1 - Electrophoresis in agarose gel of amplicons (100pb) of nested-PCR for CMV in enteric tissue of both UC and colorectal cancer patients. L ladder 100pb, lines 1 and 14 control positive, line 16 control negative and lines 2-15 positives CMV. 

colitis. Rev. Inst. Med. trop. S. Paulo, 50(2): 83-87, 2008.

The enteric tissue samples of the 14 patients with colorectal cancer were analyzed by immunohistochemistry for CMV antigens detection been all of them negative. In the immunohistochemistry of the enteric tissue samples of the 21 patients with UC, CMV antigens were detected in epithelial cells of mucosa, $12(57.1 \%)$ cases as shown in Figure 2.
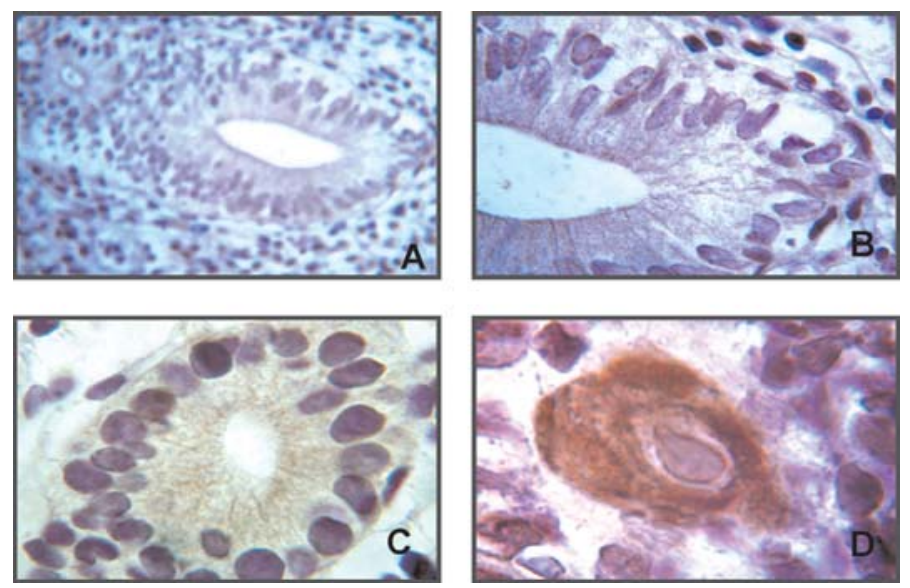

Fig. 2 - Immunohistochemical staining with monoclonal antibody for CMV in enteric tissue of UC patients. Absence staining in A and B (200 and 400X), and positive staining for CMV in $\mathrm{C}$ and $\mathrm{D}$ (200 and 400X).

CMV detection in the enteric tissue samples by immunohistochemistry and PCR showed similar results with the only exception of one ulcerative colitis participant that had CMV detected only by immunohistochemistry.

Among the seven patients having ulcerative colitis and in treatment with immunosuppressive drugs, five $(71.4 \%)$ had CMV detected in the enteric tissue samples, while it occurred in only six of $14(42.9 \%)$ ulcerative colitis participants not using immunosuppressive drugs ( $p=$ $0.3615)$.

The frequency of CMV detected in tissues samples by PCR and/or immunohistochemistry was significantly higher in the ulcerative colitis patients $(12 / 21,57.1 \%)$ than in those having colorectal cancer $(2 / 14$, $14.3 \%)(p=0.0156)$, as shown in Table 2 and in Figure 3.

\section{- Ulcerative colitis $\square$ Colorectal cancer}

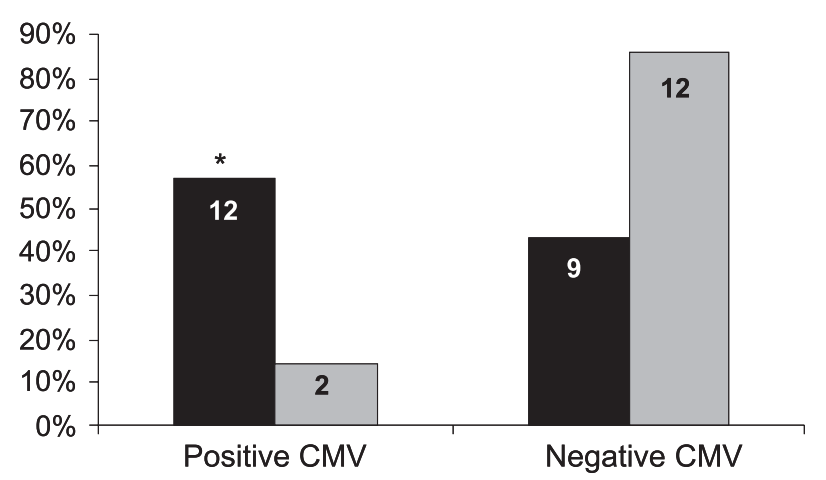

Fig. 3 - Positivities for CMV observed in enteric tissues of UC and colorectal cancer patients (* significant difference- $p$ 0.015).

\section{DISCUSSION}

Gastrointestinal lesions caused by CMV have been increasingly diagnosed, due to an improvement on diagnostic methods as well as an increasing on AIDS, transplanted and patients receiving immunossupressive chemotherapy ${ }^{21}$. In the present study, CMV was detected in $65.7 \%$ of the blood samples of the participants of the study independently of the disease. Considering that more than $95 \%$ of the adult population from Ribeirão Preto Region is infected by CMV, probably, the virus detected in blood leukocytes might not be related to any enteric disease or even to be in a latent form ${ }^{12,18}$. Thus, we decided to exclude these results of our final analysis and conclusions and to base it only on CMV detection in tissue samples.

Despite various studies showing a role of CMV in the colorectal cancer, we demonstrated a low frequency of virus in these patients (14.3\%), suggesting no association of CMV with human colorectal cancer ${ }^{3,8}$. These results, however, do not exclude the possibility of a "hit-and-run" hypothesis that claims a virus can mediate cellular transformation through an initial 'hit', while maintenance of the transformed state is compatible with loss ('run') of viral molecules. Although the concept of hit-and-run transformation has been controversial, it remains as a plausible explanation for the observations of neoplasm transformation without virus, following in vitro transfection of herpesvirus and cytomegalovirus DNAs, which have been made by multiple laboratories over more than two decades ${ }^{5,17}$. Therefore, in our study, the results obtained by the colorectal cancer group of patients were compared with those from the ulcerative colitis group.

Since 1961, many authors have reported an association of CMV infection with ulcerative colitis ${ }^{11,14}$. However, the frequency of this association remains unclear. In the present study, CMV was detected in more than half of the enteric tissues of patients with ulcerative colitis. The frequency of CMV infection in the ulcerative colitis patient group was significantly higher than that observed for colorectal cancer patients suggesting that this virus could be associated to ulcerative colitis. This higher frequency of CMV in ulcerative colitis patients compared to colorectal cancer patients, a disease that has also been associated with CMV infection, make us to suppose that in an ideal comparison, with control individuals without enteric disease and having an even lower frequency of CMV, this significant difference would be even greater.

The exact nature of the CMV association with ulcerative colitis is not clear. It has been suggested that CMV colitis could be a primary disease that could evolve to ulcerative colitis ${ }^{11,13}$. ORVAR et al. ${ }^{11}$ proposed that viral proteins expressed on the cell surface of the CMV might initiate an autoimmune response in the susceptible host leading to inflammatory bowel disease. CMV infection in tissue culture cause direct induction of MHC class I surface antigen expression and cytokine production of monocytes ${ }^{13,19}$. It could lead to an autoimmune disorder and to result in ulcerative colitis. As an alternative explanation for the presence of CMV in ulcerative colitis tissues, the virus has a propensity to localize in inflammation areas infecting tissues of granular growth, such as ulcerative colitis ulcers or to invade areas of mucosa with preexisting inflammation, but without causing the intestinal inflammatory illness ${ }^{6,15}$. Finally, mononuclear cells loading latent phase CMV could be attracted to the ulcerative colitis inflammation and to 
MARIGUELA, V.C.; CHACHA, S.G.F.; CUNHA, A.A.; TRONCON, L.E.A.; ZUCOLOTO, S. \& FIGUEIREDO, L.T.M. - Cytomegalovirus in colorectal cancer and idiopathic ulcerative colitis. Rev. Inst. Med. trop. S. Paulo, 50(2): 83-87, 2008.

concentrate locally the viral DNA ${ }^{15}$. Thus, CMV infection could be a causative of ulcerative colitis or to occur as a consequence of ulcerative colitis injuries in the intestinal mucosa.

CMV infection was detected in the enteric tissue of $71.4 \%$ (five of seven) of the immune suppressed ulcerative colitis patients while that infection occurred in $42.9 \%$ (six of 14) of those non immune suppressed patients of the same group.

We found more than a double of CMV infections in UC enteric tissues than was reported by TAKAHASHI \& TANGE, in Japan, that found CMV in only $21 \%$ of 39 UC enteric biopsies analyzed by immunohistochemistry ${ }^{19}$. The higher positivity for CMV observed in our study, 57\%, was confirmed by PCR detection of CMV genome in the same tissue samples with only one exception. We have no explanation for this difference of positivity to CMV in enteric tissues of UC patients of Brazil and of Japan. The larger frequency of enteric attack by CMV in the immune suppressed has also been reported by other authors. It could be explained by the opportunistic behavior of CMV initiating viral replication cycle from previously latent virus ${ }^{13,19}$. The reactivation of latent infection by CMV is considered as responsible for the worsening of ulcerative colitis in some cases reported as resistant to steroid treatment $t^{2,8,19,20}$.

In short, we observed that CMV was more frequent in ulcerative colitis than in colorectal cancer tissue, and it suggests an association between CMV and ulcerative colitis. However, this is an analysis based on a low casuistic and further studies including larger numbers of participants are necessary to confirm our data.

\section{RESUMO}

\section{Citomegalovírus em câncer coloretal e colite idiopática ulcerativa}

Os Cytomegalovírus (CMV) são um gênero da família Herpesviridae, que pode estar associado a síndromes gastrointestinais. No presente trabalho buscamos uma possível associação da infecção por CMV com câncer coloretal e retocolite ulcerativa (RCU). Amostras de sangue e tecido entérico de 14 pacientes com câncer coloretal e 21 com RCU foram submetidas a uma nested-PCR que amplifica parte do gene gB do CMV e a uma imunohistoquímica utilizando um anticorpo monoclonal específico para proteína IE 76Kda de CMV. CMV foi detectado pela nested-PCR em sangue e/ou tecido entérico de 9 $(64,3 \%)$ dos pacientes com câncer coloretal e $16(76,2 \%)$ dos pacientes com RCU. Na imunohistoquímica foram observadas $12(57,1 \%)$ amostras positivas para CMV nos pacientes com RCU e nos pacientes com câncer coloretal o CMV não foi detectado em nenhuma amostra. A positividade das infecções no grupo de pacientes com RCU (12/21, $57.1 \%)$ foi significantemente mais alta $(p=0,015)$ que aquela observada nos pacientes com câncer coloretal $(2 / 14,14.3 \%)$. Estes resultados sugerem uma associação da presença de CMV no tecido entérico com RCU.

\section{ACKNOWLEDGEMENTS}

We acknowledge Dr. Victor Hugo Aquino for review of the manuscript, Dr. Omar Feres and Dr. Jose Joaquim Ribeiro da Rocha for providing of colorectal cancer samples.

\section{REFERENCES}

1. AQUINO, V.H. \& FIGUEIREDO, L.T.M. - Cytomegalovirus infection in renal transplant recipients diagnosed by nested-PCR. Braz. J. med. biol. Res., 34: 93-101, 2001.

2. BERK, T.; GORDON, S.J.; CHOI, H.Y. \& COOPER, H.S. - Cytomegalovirus infection of the colon: a possible role in exacerbations of inflamatory bowel disease. Amer. J. Gastroent., 80: 355-360, 1985.

3. CINATL, J.; SCHOLZ, M.; KOTCHETKOV, R.; VOGEL, J.V. \& DOERR, H.W. Molecular mechanisms of the modulatory effects of HCMV infection in tumor cell biology. Trends Molec. Med., 10: 19-23, 2004.

4. CUNHA, A.A.; MARIN, L.J.; AQUINO, V.H. \& FIGUEIREDO, L.T.M. - Diagnosis of cytomegalovirus infections by qualitative and quantitative PCR in HIV infected patients. Rev. Inst. Med. trop. S. Paulo, 44: 127-132, 2002.

5. DONIGER, J.; MURALIDHAR, S. \& ROSENTHAL, L.J. - Human cytomegalovirus and human herpesvirus 6 genes that transform and transactivate. Clin. Microbiol. Rev., 12: 367-382, 1999.

6. GOODGAME, R.W. - Gastrointestinal cytomegalovirus disease. Ann. intern. Med., 119: 924-935, 1993.

7. GREER, C.E.; PETERSON, S.L.; KIVIAT, N.B. \& MANOS, M.M. - PCR amplification from paraffin-embedded tissues. Effects of fixative and fixation time. Amer. J. clin. Path., 95: 117-124, 1991.

8. HARKINS, L.; VOLK, A.L.; SAMANTA, M. et al. - Specific localization of human cytomegalovirus nucleic acids and proteins in human colorectal cancer. Lancet, 360: 1557-1563, 2002.

9. JEWELL, D.P. - Ulcerative colitis. In: FELDMAN, M.; SLEISENGER, M.H. \& SCHARSCHIMDT, B.F., ed. Sleisenger \& Fordtran's gastrointestinal and liver disease: pathology, diagnosis and management. 6. ed. Philadelphia, Saunders, 1998. p. $1735-1761$.

10. MOCARSKI, E.S. \& COURCELLE, C.T. - Cytomegalovirosis and their replication. In: KWIPE, D.M. \& HOWLEY, P.M., ed. Fields Virology. 4. ed. Philadelphia, Lippincott, 2001. p. 2629-2673.

11. ORVAR, K.; MURRAY, J.; CARMEN, G. \& CONKLIN, J. - Cytomegalovirus infection associated with onset of inflammatory bowel disease. Dig. Dis. Sci., 38: 2307-2310, 1993.

12. PASS, R.F. - Cytomegalovirus. In: KWIPE, D.M. \& HOWLEY, P.M., ed. Fields Virology. 4. ed. Philadelphia, Lippincott W\&W, 2001. p. 2675-2705.

13. PFAU, P.; KOCHMAN, M.L.; FURTH, E.E. \& LICHTENSTEIN, G.R. - Cytomegalovirus colitis complicating ulcerative colitis in the steroid-naive patient. Amer. J. Gastroent., 96: $895-899,2001$

14. POWELL, R.D.; WARNER, N.E.; LEVINE, R.S. \& KIRSNER, J.B. - Cytomegalic inclusion disease and ulcerative colitis. Report of a case in a young adult. Amer. J. Med., 30: 334-340, 1961.

15. ROSKELL, D.E.; HYDE, G.M.; CAMPBELL, A.P.; JEWELL, D.P. \& GRAY, W. - HIV associated cytomegalovirus colitis as a mimic of inflammatory bowel disease. Gut, 37: $148-150,1995$

16. SAMBROOK, J.; FRITSCH, E.F. \& MANIATIS, T. - Molecular cloning: a laboratory manual. 2. ed. Plainview, Cold Spring Harbor Laboratory, 1989. p. E.3-E.4.

17. SHEN, Y.; ZUH, H. \& SHENK, I. - Human cytomegalovirus IE1 and IE2 proteins are mutagenic and mediate "hit-and-run" oncogenic transformation in cooperation with the adenovirus E1A proteins. Proc. nat. Acad. Sci. (Wash.), 94: 3341-3345, 1997. 
MARIGUELA, V.C.; CHACHA, S.G.F.; CUNHA, A.A.; TRONCON, L.E.A.; ZUCOLOTO, S. \& FIGUEIREDO, L.T.M. - Cytomegalovirus in colorectal cancer and idiopathic ulcerative colitis. Rev. Inst. Med. trop. S. Paulo, 50(2): 83-87, 2008.

18. SINCLAIR, J. \& SISSONS, J.G.P. - Human cytomegalovirus: pathogenesis and models of latency. Semin. Virol., 5: 249-258, 1994

19. TAKAHASHI, Y. \& TANGE, T. - Prevalence of cytomegalovirus infection in inflammatory bowel disease patients. Dis. Colon Rectum, 47: 722-726, 2004.

20. VEJA, R.; BERTRÁN, X.; MENACHO, M. et al. - Cytomegalovirus infection in patients with inflammatory bowel disease. Amer. J. Gastroent., 94: 1053-1056, 1999.
21. WADA, Y.; MATSUI, T.; MATAKE, H. et al. - Intractable ulcerative colitis caused by cytomegalovirus infection: a prospective study on prevalence, diagnosis, and treatment. Dis. Colon Rectum, 46 (suppl. 10): S59-S65, 2003.

Received: 2 April 2007

Accepted: 29 January 2008 